УДК 94(4)«1918»+94(477)«1918»

DOI $10 / 15421 / 312009$

Б. В. Малиновский,

Т. В. Малиновская

Днипровский начиональный университет имени Олеся Гончара

\title{
КУКАВСКОЕ ВОССТАНИЕ, АВГУСТ 1918 ГОДА: УКРАИНСКИЕ ГЕТМАНСКИЕ ВЛАСТИ, АНТИГЕТМАНСКАЯ ОППОЗИЦИЯ, АВСТРО-ВЕНГЕРСКИЕ ВОЙКА
}

\begin{abstract}
Малиновский Б. В., Малиновская Т. В. Кукавское восстание, август 1918 года: украинские гетманские власти, антигетманская оппозиция, австро-венгерские войска

Статья посвящена событиям крупного антиправительственного вооруженного выступления в Подольской губернии (Украинская Держава) в августе 1918 г. В работе предпринята попытка выяснить цели восстания и определить состав его участников.
\end{abstract}

Ключевые слова: Кукавка, восстание, Украинская Держава, гетман Павел Скоропадский, австровенгерские войска в Украине (1918).

Малиновський Б. В., Малиновська Т. В. Кукавське повстання, серпень 1918 року: українська гетьманська влада, антигетьманська опозиція, австро-угорські війська

У статті висвітлено події антиурядового збройного виступу в Подільській губернії (Україиська Держава) в серпні 1918 р. У роботі здійснено спробу з'ясувати мету повстання й визначити склад його учасників.

Ключові слова: Кукавка, повстання, Україиська Держава, гетьман Павло Скоропадський, австроугорські війська в Україні (1918).

Malinovskij B. V., Malinovskaja T. V. Der Aufstand in Kukawka, August 1918: die Behörden des Ukrainischen Staates, die antihetmanischen Opposition, die österreichisch-ungarischen Truppen

Die Erforschung der Dienstdokumentation der Behörden des Ukrainischen Staates (mit Hetman Pavlo Skoropadskij an der Spitze) und des Kommandos der in der Ukraine stationierten österreichisch-ungarischen Truppen lāsst die Ziele, den Charakter und den Bestand der Teilnehmer des Aufstandes in Kukawka (Podolien) im August 1918 bestimmen, die Folge der mit diesem Aufstand verbundenen Ereignisse rekonstruieren.

Der Aufstand wurde von den ehemaligen Funktionāren der Ukrainischen Volksrepublik organisiert. Er wurde als Teil des gesamten Volksaufstandes gedacht. Sein Programm hat die Liquidierung des Hetmanats, die Wiederherstellung der Ukrainischen Volksrepublik, die Vertreibung aus der Ukraine der den Hetman unterstützten deutschen und österreichisch-ungarischen Truppen, die Vernichtung des Großgrundbesitzes in der Ukrame, die Verteilung der Gutsbesitzländereien unter den Bauern vorgesehen. Dem Vorbild der Teilnehmer der Antiregierungsbewegung 1768 („Koliiwschtschma“) verınutlich folgend wollten die Aufständischen diejenigen vernichten, die sie für Unterdrücker des Ukrainischen Volkes gehalten haben, vor allem Großgrundbesitzer.

Dem Aufstand ging eine gründliche Vorbereitung voran. Seine Teilnehmer waren gut bewaffnet, hatten einen durchdachten Aktionsplan. Die in den Dörfern formierten Kampfgruppen bestanden überwiegend aus den ehemaligen Angehörigen der russischen Zarenarmee, Veteranen des 1. Weltkrieges. Am 14. August hat sich ein Teil von Kampfgruppen im einen großen Truppen vereinigt. In den nāchsten Tagen hat er einen Streifzug durch das Territorium von Mogilewskij, Jampolskij und Brazlawskij Kreise unternommen, andere Kampfgruppen vereinigt und versucht breite Kreise der Bevölkerung in den Kampf einzuschalten.

Die Berechnung für die Teilnahme am Aufstand einer großen Anzahl von Bauern erwies sich als fehlerhaft. Die Bewegung wurde nicht massenhaft. Die Gesamtzahl der Teilnehmer hat offensichtlich 3000 Menschen nicht uberschritten. Gegen Ende August wurde die aufständische Truppe nach einer Reihe von Zusammenstößen mit den österreichisch-ungarischen Kriegseinheiten liquidiert.

Schlüsselwörter: Kukawka, der Aufstand, Ukrainische Dershawa (Ukrainischer Staat), Hetman Pavlo Skoropadskij, österreichisch-ungarischen Truppen in der Ukraine (1918). 
Malynovsky B. V., Malynovska T. V. Uprising in Kukavka, August 1918: Ukrainian hetman authorities, antihetman opposition, Austrian-Hungarian forces.

The study of the official documentation of the Ukrainian State authorities (the Ukrainian state headed by Hetman Pavlo Skoropadskiy) and the Austro-Hungarian troops command of stationed in Ukraine makes it possible to determine the goals, nature and staff of the participants in the uprising in Kukavka (Podolia) in August 1918 and to reconstruct the sequence of events connected with this uprising.

The uprising was organized by former executives of the Ukrainian People's Republic. It was conceived as part of a public uprising. Its programme provided for liquidation of the hetman state, restoration of the Ukrainian People's Republic, expulsion of the German and Austro-Hungarian troops supporting the hetman, destruction of large landholdings in Ukraine and distribution of landowners' land among the peasants. Probably, following the example of the participants in the anti-government movement in Ukraine in 1768 (Koliivshchyna), the rebels of Kukavka intended to exterminate those who were considered as the oppressors of the Ukrainian people, especially the of estate owners.

The uprising was preceded by thorough preparation. The inembers were well armed and had a considered plan of action. The battle groups formed in the villages consisted mainly of former military men of the Russian tsarist army, the veterans of World War I.

On August 14, in Kukavka, the part of the combat groups united into a large detachment. In the following days, the detachment raided the territory of Mogilev, Yampolsky and Bratslav districts, absorbing the rest of the battle groups and trying to raise wide circles of population to fight.

The plan of involving of a large number of peasants into the uprising failed. The movement did not become widespread. The total number of the participants, did not exceed three thousand people. By the end of August, the rebel army had been eliminated after a series of clashes with Austro-Hungarian military units.

Key words: Kukavka, uprising, the Ukrainian State, Hetman Pavlo Skoropadskiy, Austro-Hungarian troops in Ukraine (1918).

Постановка проблемы. Обзор научных публикаций. Все семь с половиной месяцев своего правления Украиной (май - середина декабря 1918 г.) администрация гетмана Павла Скоропадского провела в напряженной борьбе с вооруженной оппозицией. В разных частях страны происходили антиправительственные выступления, действовали многочисленные партизанские отряды. Силам правопорядка - Державной варте (правоохранительный орган гетманской Украинской Державы) и размещенным в Украине австровенгерским и германским войскам - стоило немалого труда сохранять контроль над охваченными протестным движением регионами.

Чего добивались противники гетмана? Кто они были? Правда ли, что деятельность подполья, как утверждали его участники, пользовалась всенародной поддержкой? Являлось ли антигетманское повстанческое движение массовым? Ставить эти вопросы уместно, поскольку попытки получить на них ответы, предпринятые в исторической науке ранее, не дали исчерпывающих, исключающих сомнения результатов.

К числу недостаточно изученных эпизодов истории повстанчества принадлежит крупное восстание в Подольской губернии в августе 1918 г., начавшееся в селе Кукавка Могилевского уезда и затем распространившееся на другие села Могилевского, Ямпольского и Брацлавского уездов. В исторической науке нет работ, специально посвященных этому событию. Причины и ход восстания кратко рассмотрены в общих трудах о политической борьбе в Подольской губернии или Украине в целом (статьи и книги А. Антонишина, К. Гуменюка, П. Захарченко, А. Лекаpa, В. Лободаева, И. Ратушняка, Е. Тычины и других исследователей $[1 ; 4-7 ; 11 ; 15])$.

Цель исследования - опираясь на данные служебной документашии украинских органов власти и австро-венгерского командования, выяснить задачи, которые ставили перед собой участники вооруженного выступления в Кукавке, а также определить их состав.

Источниковая основа исследования включает следующие группы документов: сообщения гетманских должностных лиц (донесения уездных старост и сводки Осведомительного отдела Департамента Державной варты Министерства внутренних дел Украинской Державы); материалы следствия, проведенного украинскими властями после подавления восстания; сообщения главного командования австро-венгерских войск в Украине (вечерние доклады, Abendmeldungen) $[2$, c. $45-58,60,62 ; 3$, c. $279,280,323-325$; 9 , c. $83-100 ; 13$, c. $187-189 ; 16 ; 17 ; 18 ; 19 ; 20]$.

Изложение основного материала. Как следует из этих документов, вдохновителями и организаторами восстания являлись бывшие деятели Украинской Народной Республики, главным образом представители 
Украинской партии социалистов-революционеров и Украинского крестьянского союза [1, c. $168 ; 5$, c. $100 ; 6$, c. 164,165$]$.

Цели, которые они преследовали, сотрудник прокуратуры, выяснявший этот вопрос, выразил так: «Насильственным путем восстановить власть Центральной Рады и уничтожить тем самым власть Пана Гетмана, [...] уничтожить в [Могилевском] уезде весь тот элемент, который косвенно или прямо охраняет помещичьи земли (управляющих, арендаторов, [Державную] Варту и т.д.), отобрать последние и предоставить их народу» $[20$, c. 6]. В задачи повстанцев входило также «дать надлежащий отпор пришельцам - австрийцам и немцам» (размещенным в Украине австро-венгерским и германским войскам) $[5$, c. 100$]$.

Восстанию предшествовала тщательная подготовка. Был разработан план действий, обозначен круг участников. В ряде сел и местечек Могилевского, Брацлавского и Ямпольского уездов (возможно, также и в других уездах Подольской губернии) были образованы боевые группы. Предполагалось, видимо, что в условленное время несколько таких групп объединятся и начнут выступление, а остальные примкнут к ним в дальнейшем. По замыслу инициаторов выступления, созданное таким образом повстанческое войско, вовлекая в борьбу широкие массы, должно было стать основой большой народной армии.

Круг людей, согласившихся принять участие в восстании, вероятно, охватывал главным образом бывших фронтовиков, ветеранов Первой мировой войны. Многие из них в 1917 - начале 1918 г. числились в рядах вольного казачества - вооруженного формирования УНР из добровольцев, упраздненного незадолго до гетманского переворота $[5$, c. $103 ; 7$, c. 219$]$.

Базой для подготовки восстания являлось село Кукавка Могилевского уезда. Место подходило для этой цели, поскольку не контролировалось властями. Расположенные на границе зон ответственности двух австро-венгерских комендатур, Кукавка и соседние села Ираклиевка, Жеребиловка и Нижний Ольчедаев обеими этими комендатурами были оставлены без внимания [3, с. 323; 20, с. 6].

Украинская администрация знала о том, что эти села «долгое время служили местом, куда стекались всякого рода неблагонадежные элементы, являясь, таким образом, центром [антиправительственной] агитации Могилевского и соседних уездов», что в Кукавке и в лесу рядом с ней «сходятся агитаторы, созывают сходы и подготовляют народ к выступлению» [20, с. 6]. Могилевский уездный староста неоднократно обращался к командирам австро-венгерских гарнизонов Могилева и Жмеринки с просьбой изъять оружие у населения Кукавской волости, однако необходимые меры так и не были приняты [3, c. 323].

По данным гетманских властей, восставшие получили оружие от могилевского уездного коменданта Андрея Вовка, будущего генерала армии УНР и ее военного министра (о нем см.: [5, с. $100 ; 14$, с. 173-175]). В июле 1918 г. из комендантского арсенала якобы было выкрадено 1467 винтовок, 21 пулемет и большое количество патронов. Очевидно, при содействии Вовка это оружие оказалось в руках повстанцев $[1$, с. $168 ; 5$, с. 100]. И не только это. По данным следствия, «розданные пулеметы надо [было] считать десятками, а винтовки - тысячами» [16, с. 181].

В подчинении у коменданта находилось особое военное подразделение - добровольческая охранная сотня. Это подразделение, как и персонал комендатуры, по данным следствия, состояло из сторонников УНР. Как говорится в дневнике княгини Е.Н. СайнВитгенштейн, очевидицы событий, многие из этих людей имели весьма неоднозначную репутацию («из каторжников и уголовных», [12, c. 225]). Расследование выявило причастность служащих комендатуры к подготовке восстания. В документах следствия утверждалось: « несомненностью установлена организация восстания при ближайшем участии штаба уездной комендатуры и подведомственных коменданту воинских команд» [16, с. 181].

Следствие выяснило, что атаманы куреней, подчиненные А. Вовка, совершали поездки по уезду, проводя агитацию «против существующего Державного строя и [в пользу] необходимости вооруженного восстания». Сам Вовк открыто заявлял о неприятии гетманской власти. В разговоре с начальником пулеметной команды Клечковским он сказал, «что близок переворот и он, Вовк, будет рад свержению Пана Гетмана, являющегося, по его словам, “кацапским правителем") [16, c. 181]. Как показало расследование, к проведению агитации и распространению оружия были причастны также сельские учителя и сотрудники «Просвиты» $[16$, с. $181 ; 20$, с. 6$]$.

Ведущую роль среди организаторов восстания играли бывшие члены Украинской Центральной Рады - атаманы вольных казаков Гордей Мазур и Алексей Козел, учителя Черный и Мельник, писарь комендантской сотни Добрянский $[5$, с. $100 ; 7$, с. $219 ; 16$, с. 181]. Главным командиром повстанцев на на- 
чальном этапе восстания являлся крестьянин села Сербы М. Пастухов. Следствие позже установило, что он был связан с организацией УПСР в Могилеве-Подольском, а накануне восстания ездил «за инструкциями в Одессу» $[20$, c. 6$]$.

По данным украинских разведывательных служб, Одесса в конце лета 1918 г. являлась центром подготовки всеукраинского вооруженного выступления. В докладе директора Департамента Державной варты (10 августа 1918 г.) о ситуации в Одессе говорилось: «Местные революционные организации социалистов-революционеров, социал-демократов и самостийников, объединивштись в национальный Украинский союз, ведут, частью легально - при посредстве союзных им культурно-просветительных учреждений, частью тайно усиленную работу по подготовке всеобщего восстания на Украине, каковое приурочивается ко второй половине августа месяца сего года, ко времени сбора урожая, когда легко будет поднять: в деревнях селянство на почве невыдачи австро-германцам хлеба, а в городах пролетариат - на почве дороговизны и недоедания, так как-де в это время будет ощущаться острая нужда в хлебе. Конечная цель восстания - ниспровержение Пана Гетмана и его Правительства за стремление их к русской ориентации: Пан Гетман будет арестован и затем увезен из Киева, члены же Правительства подвергнуты аресту» [8, с. 239].

Как утверждалось в этом докладе, главным очагом восстания должен был стать Звенигородский уезд, куда отправлялись «небольшими партиями офицеры и казаки». Сoобщалось также, что с помощью социал-демократов из Западной Украины велась агитация среди австрийских военнослужащих (имевшая «большой успех»), и что общее число вовлеченных в заговор «бойцов-украинцев» составляло двести тысяч человек («хорошо вооруженных и снабженных артиллерией»), а австрийских подданных, в том числе Украинских сечевых стрельцов, - сто тысяч $[8$, с. 239].

О том, что в Одессе группировались силы экстремистов, знало и командование размещенных в Украине войск Центральных держав. По сведениям германских военных властей, в этом городе действовала террористическая организация, которая была связана с российскими эсерами, совершившими 30 июля 1918 г. покушение на командующего германскими войсками в Украине фельдмаршала Г. Эйхгорна $[21$, с. 95$]$.

Если эти данные украинских и германских осведомительных служб соответствова- ли действительности, то, вероятно, выступление в Подольской губернии планировалось как часть задуманного украинскими (а также российскими?) леворадикальными партиями всеукраинского восстания.

Инициаторы выступления в Подольской губернии, очевидно, рассчитывали на поддержку со стороны некоторых австро-венгерских частей. Готовясь к выступлению, заговорщики установили контакты с солдатами 20-го австро-венгерского полка, размещенного в Могилевском уезде. Полк состоял преимущественно из украинцев-галичан. Многие среди них разделяли требования украинской республиканской оппозиции и были готовы способствовать свержению гетманского режима.

О настроениях в австро-венгерских частях, дислоцированных на территории Подольской губернии, руководству Державной варты в августе 1918 г. было известно следующее: «В Жмеринском [25-м] австрийском корпусе продолжается антигерманская и антиправительственная [направленная против гетманского правительства] большевистская пропаганда, которая, если не будут приняты серьезные меры, безусловно, вызовет большие бедствия на Украине, так как эта пропаганда подстрекает крестьян к вооруженному выступлению против германцев, мадьяр, а также против правительственных чинов Украины. В особенности в этом отношении изощряются так называемые «австрийские украинцы», которые положительно при каждом удобном случае ведут усиленно эту пропаганду» $[9$, с. 84, 85].

Начало восстания в Кукавке было намечено на 14 августа 1918 г. Выбор был обусловлен тем, что «в это время предполагалась смена Могилевского Австро-Венгерского Гарнизона, долженствовавшего отправиться на [Итальянский] фронт, каковое обстоятельство, по мнению повстанцев, прекрасно информированных, должно было им облегчить движение на Могилев, где предполагалось уничтожение буржуев, проживающих здесь беглых помещиков и [представителей] интеллигенции» $[20$, с. 6$]$.

Согласно сведениям властей, повстанцы имели и другую причину назначить начало выступления на 14 августа - они намеревались освободить находивптихся в заключении служащих комендантской сотни $[2$, с. 45$]$. За несколько дней до начала восстания, 5 августа, в селе Мытки Могилевского уезда был ограблен некий Аврум Энгель. 8 августа в Баре австрийские жандармы и сотрудники варты по подозрению в совершении этого преступления задержали командира охранной 
конной полусотни при могилевском коменданте Шелезнева и двенадцать казаков. Некоторых из этих людей обвиняли в совершении также и других преступлений. До рассмотрения дела австрийским военно-полевым судом арестованных держали в Баре под стражей $[2$, c. $45 ; 16$, с. 14$]$. По имевшимся у властей данным, повстанцы решили ускорить выступление, чтобы предупредить суд и тем самым спасти обвиняемых от казни по его приговору $[1$, с. $167 ; 2$, с. $45 ; 3$, с. $280 ; 5$, с. 101 ; 17, c. 44 об.].

Выступление в Кукавке, как и было запланировано, началось 14 августа. Часть боевых групп объединилась в крупный отряд. В последующие дни он совершил рейд по территории Могилевского, Ямпольского и Брацлавского уездов, собирая остальные боевые группы и пытаясь вовлечь в восстание широкие массы. Продвигаясь через села и имения, повстанцы уничтожали сотрудников варты и служащих крупных хозяйств. Направленные на подавление восстания австро-венгерские подразделения несколько раз нанесли повстанцам поражение. 25 августа повстанческое войско, вернувшееся к тому времени в район Кукавки, было окончательно разгромлено. Отдельные группы восставших продолжали действовать еще несколько дней, но затем также были ликвидированы.

Движение не приняло массового характера. По некоторым оценкам, численность участников восстания достигала десяти тысяч человек $[4$, с. 147]. Следует предположить, что реальное число было втрое-вчетверо меныше. Попытки повстанцев привлечь на свою сторону население оказались безуспешными. Даже среди членов заранее сформированных боевых групп, очевидно, далеко не все приняли участие в восстании. Одни уклонились, а другие, хотя и присоединились к повстанческому войску, но затем покинули его, убедившись, что дело не идет на лад.

Так, к примеру, поступил житель Холодовской волости Брацлавского уезда Мирон Зевык. Вместе с группой повстанцев (около ста человек), возглавляемой бывшим членом Центральной Рады и Всеукраинского совета крестьянских депутатов Иваном Бобом, 20 августа Зевык отправился из Холодовки в Михалевку и затем в Шуранский лес (у села Шура), чтобы присоединиться к кукавским повстанцам, приближавшимся тогда к этому району. Однако в Шуранском лесу, как сообщалось в материалах следствия, «Мирон Зевык оставил шайку Боба и возвратился в свое село, унеся с собою винтовку и сигнальный рожок. По словам священника с[ела] Холодовки Мисевича через несколько дней $[\ldots]$ к нему зашел вечером Мирон Зевык и просил указать ему, где он может увидеть австрийского офицера для того, чтобы сознаться в своем участии в банде Боба и назвать крестьян, находящихся в этой банде» $[18$, c. 8$]$.

Повстанцы делали все возможное, чтобы расширить свой состав - использовали и убеждение, и принуждение, обещали заплатить. Так, в селе Копиевке 18 августа Ефиму Деревяго «главарь восставших предложил [...] присоединится к их компании за плату в 150 рублей в месяц». Деревяго отказывался, но его насильно удержали в повстанческом отряде. После того, как отряд двинулся из Копиевки в Кобылевку, «по дороге Деревяга взял себе шашку и винтовку и ушел с ними к себе домой, так как не пожелал принимать участие в грабежах, убийстве помещиков и в изгнании австрийцев, к чему призывал главарь банды» $[18$, с. 8$]$.

Два жителя Кобылевки, Алексей Цвигун и Захарий Пантелеймонов, стояли возле хаты Цвигуна, когда мимо шел обоз повстанцев (18 августа). Их схватили, усадили на одну из подвод и повезли с собой. Через время, улучив момент, когда за ними никто не следил, они бежали $[18$, с. 8$]$.

Характеризуя отношение крестьян к повстанцам, могилевский уездный староста сообщал главе губернской администрации (6 сентября 1918 г.): «Обращаясь к причинам относительной неудачи восстания, должен констатировать, что таковое не разрослось в силу несочувствия ему самого населения. Было много случаев, где, присоединившись под угрозой смерти к бандам повстанцев, присоединившиеся селяне при первом удобном случае разбегались, бросая оружие. Найденные в нескольких местах трупы, в числе восьми, неизвестных лиц, по предположению принадлежали к лицам, не желавшим пристать к повстанцам и за это расстрелянными бандитами. В некоторых селениях, напр [имер, в] м[естечке] Ялтушкове, Поповцах, Жеребиловке, Кукавке, крестьяне сорганизовались для недопущения к себе агитаторов и бандитов и выдачи их властям» $[16$, c. $155 ; 10$, c. 155$]$.

Надежды повстанцев на помощь со стороны галичан на австро-венгерской службе также не оправдались. Бунт, поднятый в ночь на 20 августа в Могилеве-Подольском состоявшими из славян подразделениями австро-венгерского 20-го полка, уже к утру был подавлен. В бою с венгерскими подразделениями мятежники потерпели поражение и сложили оружие $[2$, с. $50 ; 9$, с. $83,84,85,90$, $99,100 ; 12$, c. 225,226$]$. 
Вечером 20 августа Е.Н. СайнВитгенштейн, находившаяся тогда в Могилеве, записала в дневнике: «Теперь известна подкладка всей этой истории: бунт австрийцев был подготовлен заранее в союзе с окрестными мужиками и могилевскими мещанами. Австрийцы ждали помощи мужиков и мещан, которые, однако, предпочли издали посмотреть, чья возьмет, раньше, чем ввязываться в дело. На одной из дальних улиц собралась толпа мещан, готовая идти бесчинствовать по городу, если бунтовщики возьмут верх. Австрийцы приглашали идти с собой “делать общее дело" и вовковскую банду разбойников, именуемую "державной вартой” [то есть охранное подразделение, подчиненное уездному коменданту А. Вовку, или размещенное в Могилеве отделение Державной варты]. Но вартовики разбежались от первого выстрела. Они [участники бунта] приглашали и отряд Толстикова. (Отряд организован и содержится на частные средства помещиков. Он подобран из приличных людей. Большей частью поляков. Мы их называем нашими опричниками. Этот отряд, когда варта удрала, пришел охранять [уездного] старосту, почту и даже разные пункты на улицах)» $[12$, с. 226$]$.

Некоторые участники бунта попытались присоединиться к кукавским повстанцам или же укрыться среди крестьян. «По селам много беглых солдат» - говорилось в сводке Департамента Державной варты 25 августа [2, с. 55]. 21 августа группа австро-венгерских солдат совершила нападение на село Копыстырин Ямпольского уезда [18, с. 169]. Очевидно, о действиях этой группы шла речь в сводке Департамента Державной варты: «Банда могилевских повстанщев, прибывшая в Копыстырин, Тарасовку и Пасынки, убила там землевладельца Свирского, арестовала приказного и вартового и возвратилась в Шаргородку. В имениях Зведеновке, Деребчине, Джурине и Семеновке банды причинили небольшие убытки. Сахарные заводы целы» $[9$, с. 88,89$]$.

Скорее всего, это были участники бунта 20-го полка, которые после его подавления отправились в район Шаргорода, чтобы соединиться с кукавскими повстанцами, находившимися тогда в этом районе. Солдаты, напавшие на Копыстырин, были задержаны, 29 из них - расстреляны. Дома нескольких жителей Копыстырина, присоединившихся к бунтовщикам, подверглись разрушению $[19$, c. 169$]$.

Противникам гетмана, связанным с повстанцами Могилевского уезда, не удалось вызвать восстания в других частях Подоль- ской губернии, хотя они приложили к этому все усилия. По сведениям австро-венгерских военных властей, в последних числах августа «бывшие русские офицеры» пытались организовать партизанские отряды «во многих местах севернее Жмеринки», однако успеха не достигли [19, с. 167].

В те же дни было неспокойно и в Одессе - центральном пункте левоэсеровского подполья в Украине. В сводке Департамента Державной варты 25 августа читаем: «По агентурным сведениям, среди отрядов австро-венгерских войск, расположенных в Одессе, ведется усиленная агитация и пропаганда членами партии левых социал[истов]-революционеров. Пропаганда направлена на деморализацию и склонение нижних чинов на сторону левых c[оциалистов]-p[еволюционеров], которые располагая оружием, предполагают организовать массы для выступления против украинских правительственных властей» $[2$, с. 55$]$.

Разобщенность крестьян и повстанцев стала для властей в буквальном смысле спасением. Если бы восстание получило массовую поддержку, губернская администрация и австро-венгерские военные власти, вполне возможно, не смогли бы с ним справиться. Сообщая о том, что в Ямпольском уезде большинство крестьян отказались поддержать восставших, составитель сводки Департамента Державной варты откровенно признавал: «Иначе положение могло бы быть опасным, так как австрийцы борются с восстанием не энергично» $[9$, с. 87].

Нерешительность австро-венгерского командования объяснялась в первую очередь нехваткой сил. Австро-вентерский военный контингент в Подольской губернии (как и вообще в Украине) был слишком мал для эффективного контроля над той обширной территорией, которую он занимал. Кроме того, одновременно с борьбой против кукавских повстанцев австро-венгерское командование, как отмечалось, было вынуждено усмирять мятеж своих собственных солдат.

Правоохранительная система Гетманата, испытывая недостаток сил и средств, тоже не могла противостоять масштабному повстанческому движению. Значительная часть личного состава варты и охранных подразделений не внушала доверия. Из опасения, что охранные сотни перейдут на сторону повстанцев, эти подразделения не были задействованы властями в подавлении Кукавского восстания $[9$, с. $85,86,88]$.

Подразделения варты в Подольской губернии, кроме того, что в них оставался «еще 
на службе ненадежный элемент», были плохо вооружены. Сотрудник Департамента Державной варты, оценивая состояние правоохранительных органов Подольской губернии, 23 августа в своем докладе руководству отмечал: «Вартовые на постах часто стоят с револьверами без патронов, а в лучшем случае с 2-3 патронами» $[9$, с. 86].

Итоги исследования. Изучение служебной переписки украинских гетманских и австро-венгерских властей позволяет определить цели и характер восстания в Кукавке (Могилевский уезд Подольской губернии) в августе 1918 г., реконструировать последовательность связанных с этим восстанием событий, выяснить состав его участников.

Выступление было организовано бывшими функционерами Украинской Народной Республики. Оно было задумано как часть общенародного восстания в Украине. Его программа предусматривала ликвидацию Гетманата, восстановление УНР, изгнание из Украины войск Центральных держав, уничтожение крупного землевладения и распределение помещичьей земли между крестьянами. Подобно участникам Колиивщины (и, оче- видно, по их примеру), кукавские повстанцы намеревались истребить тех, кого считали угнетателями украинского народа, прежде всего помещиков.

Выступлению предшествовала основательная подготовка. Его участники были хорошо вооружены, имели продуманный план действий. Сформированные в селах и местечках, боевые группы состояли преимущественно из бывших служащих российской царской армии, ветеранов Первой мировой войны.

14 августа в Кукавке часть боевых групп объединилась в большой отряд. В последующие дни он совершил рейд по территории Могилевского, Ямпольского и Брацлавского уездов, вбирая в себя остальные боевые группы и пытаясь поднять на борьбу широкие круги населения. Расчет на участие в восстании значительного количества крестьян, однако, оказался ошибочным. Движение не приняло массового характера. Общая численность его участников, очевидно, не превышала трёх тысяч человек. К концу августа повстанческое войско после ряда столкновений с австро-венгерскими подразделениями было ликвидировано.

\section{Библиографические ссылки}

1. Антонишин А. П. Селянсько-повстанський рух на Поділлі (квітень-листопад 1918 року). Наукові записки Вінницького державного педагогічного університету імені Михайла Кочюбинсъкого. Серія : Iсторія. Вінниця, 2007. Вип. 12. С. 165-170.

2. Архів Української Народної Республіки. Міністерство внутрішніх справ. Звіти департаментів державної варти та політичної інформації (1918-1922) / упоряд. В. Кавунник. Киӥв : Інститут української археографії та джерелознавства імені М. С. Грушевського, 2018. $612 \mathrm{c}$.

3. Гражданская война на Украине 1918-1920: сб. документов и материалов. Киев, 1967. Т. 1. Кн. 1.876 с.

4. Гуменюк К. С. Боротьба трудящих Поділля 3 австро-німецькими окупантами в 1918 р. Боротьба за владу Рад на Україні. Київ, 1977. С. 138-156.

5. Захарденко П. П. Селянська війна в Україні: рік 1918. Київ, 1997. 188 с.

6. Лекар А. М. Боротьба за владу в Подільській губернії в добу гетьманату П. Скоропадського. Записки історичного факультету Одеського національного університету. 2012. № 23. С. 159-185.

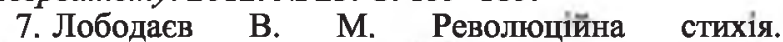
Вільнокозацький рух в Україні 1917-1918 рр. Київ, 2010, 672 c.

8. Міністерство внутрішніх справ України : події, керівники, документи та матеріали (1917-2017рр.). Київ, 2012. Т. 1: Міністерство внутрішніх справ за доби УНР та Української Держави (1917-1920 рр.). 686 с.

9. Поділля в роки громадянської війни (лютий 1918 - грудень 1920 рр.): Документи й матеріали. Вінниця, 1959. 487 с.
10. Подільський губернський староста Сергій Кисельов (1877-1937) у документах епохи / автори-упорядники О. М. Кравчук, I. I. Ратушняк, К. В. Завальнюк. Вінниця, 2016. 286 с.

11. Ратушняк I. І. Спроба відновлення правопорядку у Могилів-Подільському повіті в період Української Держави 1918 р. П'ята Могилів-Подільська науковокраєзнавча конференуія 16-17 жовтня 2015 р. : Матеріали конференуї. 2015. С. 187-204.

12. Сайн-Витгенштейн Е. Н. Дневник 1914-1918. Париж, 1986. 301 с.

13. Східне Поділля в добу Центральної Ради та гетьманату П. Скоропадського (березень 1917p. - грудень 1918 р.): зб. документів та матеріалів. Вінниця, 2008. 208 c.

14. Тинченко Я. Ю. Українське офіцерство : шляхи скорботи та забуття 1917-1921 роки. Київ, 1995. Ч. $1.259 \mathrm{c}$.

15. Тичина В. С. Боротьба проти німецьких окупантів і внутріпньої контрреволюції на Україні у 1918 році. Харків, 1968. 284 с.

16. Центральний державний архів вищих органів влади і управління України (м. Київ, Україна) (ШДАВОУ) Ф. 1793. Оп. 1. Спр. 44.

17. ЦДАВОУ. Ф. 2311. Оп. 1. Спр.119.

18. ЦИАВОУ. Ф. 2207. Оп. 1. Спр.1134.

19. ЦДАВОУ. Ф. 2311 . Оп. 1. Спр.131.

20. Центральний державний історичний архів України (м. Київ, Україна). Ф. 419. Оп. 1. Cпр.7307.

21. Чикаленко С. Х. Щоденник. Київ, 2004. Т. 2 : 1918-1919. $464 \mathrm{c}$. 


\section{References}

1. Antonishyn, A. P. (2007). Seliansko-povstanskyi rukh na Podilli (kviten-lystopad 1918 roku) [Peasant-insurgent movement in Podillya/Podolia (April-November 1918)]. Scientific notes of Vinnytsia State Pedagogical University named after Mykhailo Kotsyubynsky. Series: History, 12, 165-170 (in Ukrainian).

2. Kavunnyk, V. (Ed.). (2018). Arkhiv Ukrainskoi Narodnoi Respubliky. Ministerstvo vnutrishnikh sprav. Zvity departamentiv derzhavnoi varty ta politychnoi informatsii (1918-1922) [Archives of the Ukrainian People's Republic. Ministry of Internal Affairs. Reports of directors of departments and agents (June 1918 - January 1922)]. Kyiv: Institute of Ukrainian Archaeography and Source Studies named after M. S. Hrushevskiy (in Ukrainian, in Russian).

3. Grazhdanskaya voyna na Ukraine 1918-1920 : Sbornik dokumentov i materialov (1967) [The Civil War in Ukraine 1918-1920: A collection of documents and materials]. Vol. 1 (in Ukrainian, in Russian).

4. Humeniuk K. S. (1977). Borotba trudiashchykh Podillia $\mathrm{z}$ avstro-nimetskymy okupantamy v 1918 r. [The struggle of the workers of Podolia (Podillya) with the Austro-German occupiers in 1918]. The struggle for Soviet power in Ukraine, 138-156 (in Ukrainian).

5. Zakharchenko P. P. (1997). Selianska viina v Ukraini : rik 1918 [Peasant war in Ukraine: 1918] (in Ukrainian).

6. Lekar A. M. (2012). Borotba za vladu v Podilskii hubernii $\mathrm{v}$ dobu hetmanatu P. Skoropadskoho [Struggle for power in Podolsk province in the days of Hetman P. Skoropadsky]. Notes of the historical faculty of Odessa National University, 23, 159-185 (in Ukrainian).

7. Lobodaev V. M. (2010). Revoliutsiina stykhiia. Vilnokozatskyi rukh v Ukraini 1917-1918 rr. [Revolutionary element. Free Cossack movement in Ukraine 1917-1918] (in Ukrainian).

8. Ministerstvo vnutrishnikh sprav Ukrainy : podii, kerivnyky, dokumenty ta materialy (1917-2017 rr.) (2012) [Ministry of Internal Affairs of Ukraine: events, leaders, documents and materials (1917-2017)]. Vol.1. Kyiv (in Ukrainian, in Russian).

9. Podillia v roky hroinadianskoi viiny (liutyi 1918 hruden 1920 rr.): Dokumenty y materialy (1959) [Podillya (Podolia) during the Civil War (February 1918 - December 1920): Documents and materials]. Vinnytsia (in Ukrainian, in Russian).

10. Podilskyi hubernskyi starosta Serhii Kyselov (1877-1937) u dokumentakh epokhy (2016) [Podolsk pro- vincial mayor Sergei Kiselyov (1877-1937) in the documents of the era] (in Ukrainian, in Russian).

11. Ratushnyak I. I. (2015) Sproba vidnovlennia pravoporiadku u Mohyliv-Podilskomu poviti v period Ukrainskoi Derzhavy $1918 \mathrm{r}$. [An attempt to restore law and order in Mohyliv-Podilskyi district during the period of the Ukrainian State in 1918]. The Fifth Mohyliv-Podilskyi scientific and local lore conference, October 16-17, 2015: Proceedings of the conference, 187-204 (in Ukrainian).

12. Sayn-Wittgenstein E. N. (1986). Dnevnik 19141918 [Diary 1914-1918]. Paris (in Russian).

13. Skhidne Podillia v dobu Tsentralnoi Rady ta hetmanatu P. Skoropadskoho (berezen 1917r. - hruden 1918 r.) : Zbirnyk dokumentiv ta materialiv (2008) [Eastern Podillya/Podolia in the days of the Central Rada and the Hetmanate of P. Skoropadsky (March 1917 - December 1918): Collection of documents and materials] (in Ukrainian, in Russian).

14. Tynchenko Ya. Yu. (1995). Ukrainske ofitserstvo : shliakhy skorboty ta zabuttia 1917-1921 roky [Ukrainian officers: ways of grief and oblivion 1917-1921]. Part 1 (in Ukrainian).

15. Tychyna, V. E. (1968). Borotba proty nimetskykh okupantiv i vnutrishnoi kontrrevoliutsii na Ukraini u 1918 rots $i$ [The struggle against the German occupiers and the internal counterrevolution in Ukraine in 1918]. Kharkiv: Kharkiv University Press (in Ukrainian).

16. Tsentralnyi derzhavnyi arkhiv vyshchykh orhaniv vlady i upravlinnia Ukrainy [Central State Archive of the highest authorities and administration of Ukraine. (n.d.)], coll. 1793, aids 1, fol. 44 (in Russian).

17. Tsentralnyi derzhavnyi arkhiv vyshchykh orhaniv vlady i upravlinnia Ukrainy [Central State Archive of the highest authorities and administration of Ukraine. (n.d.)], coll. 2311 , aids 1 , fol. 119 (in Russian).

18. Tsentralnyi derzhavnyi arkhiv vyshchykh orhaniv vlady i upravlinnia Ukrainy [Central State Archive of the highest authorities and administration of Ukraine. (n.d.)], coll. 2207, aids 1, fol. 1134 (in Russian).

19. Tsentralnyi derzhavnyi arkhiv vyshchykh orhaniv vlady i upravlinnia Ukrainy [Central State Archive of the highest authorities and administration of Ukraine. (n.d.)], coll. 2311 , aids 1 , fol. 131 (in Russian).

20. Centralnij derzhavnij istorichnij arhiv (Kyiv) [Central State Historical Archive of Ukraine (Kyiv) (n.d.)], coll.419, aids 1, fol. 7307 (in Russian).

21. Chikalenko, E. (2004). Shchodennyk [Diary]. Vol. 2. Kyiv: Tempora (in Ukrainian). 